Still another course would be for a firm of publishers to bring out a purely physical paper. The stumbling-block here is the question of advertisements. According to Mr. Thiselton Dyer, scientific men are supposed to beunbusiness-like, no doubt without reason; but it may be well to remind them that most $\mathrm{j}$ urna's live on their advertisements, the reading matter being a necessary evil. It would thus be commercially impossible to run a purely physical paper, as there is no trade, except to a certain extent electrical engineering, which has much to do with physics.

It might be better to abandon the idea of a central organ for physics, and to publish a complete set of abstracts. Abstracts to be useful must be very well made, and they must be com. plete. It is very difficult to get good abstracts. The work is laborious and costly when efficiently done. Abstracts are only a developed index, and it would still be necessary that separate papers should be obtainable. Incomplete abstracting is a very common vice. It is not enough to have a few papers brought under a reader's notice: that is good when one is reading for general information in an indolent way, but it is useless in the far more common case in which he wants to know either all that has been done on a given subject, or whether some discovery has been hit upon before. A scientifically worked out subject index is also essential, and, as said before, the abstracts must be practically complete.

4, Hatherley Road, Kew Gardens, June 25.

The Glacier Theory of Alpine Lakes.

I HAVE read with interest the discussion in NATURE on the "Glacier Theory of Alpine Lakes," and I feel constrained to write now, more especially as Mr. Wallace his cited Tasmania as a country, among others, where Alpine lakes are associated with "palpable signs of glacia-ion." Having recently, with Prof. Spencer, of Melbourne University, made a visit to the central lake district of Tasmania, a few nords about the lakes may not be without interest in reference to the subject under discu-sion.

The lake district of Tasmania is situated about the centre of the island on the great central greenstone plateau, which attains to a height of $4000 \mathrm{ft}$. above sea level in places. We camped on the shores of Lake St. Clair, and remain ed there during the wh sle month of January of this year. Lake St. Clair is about $2500 \mathrm{ft}$. above the sea, and is about I I miles long by 2 broad. It uccupies a narrow valley between the Olympus Range on the one hand and the Traveller Range on the other. A depth of $590 \mathrm{ft}$. is recorded. Its basin probably lies in sandstone (carboniferous?), the structure of the adjoining mountains being sandstone capped by greenstone (diabase).

Both Prof. Spencer and myself, being believers in the glacier theory of Alpine lakes, had half expected to find evidences of glaciation, especially as we had heard of well marked signs being found on the west coast, some 50 or 60 miles to the northwest. However, we could not find the slightest trace of glacial action. From the top of Mount Olympus, rising about $2350 \mathrm{ft}$. above the surface of the lake, we got a magnificent view of the country. The Traveller Range opposite is really the edge of a great greens one plateau, stretching away with a roughly undulating surface for miles beyond. The surface of this plateau is studded all over with lakes and tarns of various sizes and at different levels. In other directions, too, lakes can be seen here and there nestling in the valleys. In all we counted between thirty and forty lakes and tarns from the top of Mount Olympus. Two small basins of water-the "Olympian Tarns"-rest on the flanks of the mountain itself. On the opposite side of Olympus from St. Clair lies Lake Petrarch, occupying an oval basin and apparently of shallow depth. This lake is about 563 ft. above St. Clair. On the right shore of St. Clair occurs another small lake (Lake Laura) $50 \mathrm{ft}$. above the former, and separated from it by a ridge about 3400 yard: across.

A characteristic feature of this district are the "button-grass" flats. These are open, marshy expanses covered with "buttongrass" (Gymnschanus spharocephalus) and other plants. They are traversed by numerous little runlets of water, which usually unite into one or more main streams. Here and there in many of them masses of greenstone protrude. Between these "Hats" are generally low ridge; of greenstone covered with Eucalyptus and Banksias, \&c. Many of these flats or marshes -as, for instance, those in the Cuvier Valley, at the head of which lies Lake Petrarch-reminded me very strongly of the

NO. I 235 , vOL. 48 ] moorland scenery in the Scottish Highlands, and the platean, already referred to, with the lakes and tarns scattered over its surface, might be a scene in Sutherlandshire. But in all our wanderings we did not find the slightest sign of glaciation either in the form of moraines or of striated rock-surfaces. We were not able to examine the lakes on the plateau mentioned, but from its configuration I am confident that evidences of glaciation do not exist. On the west cuast, notably about the Pieman River, signs of glacialion are, I believe, abundant, and numerous tarns and rock basins are associated with them. Here the neighbouring mountains are not so high as those further inland, and it was probably their proximity to the coast that was the cause, during the last glacial epoch, of glaciers being formed there and not further inland.

So then, thoug in in Tasmania there are instances of rock-basin lakes being associated with undoubted evidences of glaciation, yet, as I have shown, the glacier theory will not account for by far the greater number of the Alpine lakes on the great central greenstone plateau. I do not propose to put forth any theory to account for these lake-basins, but have put down the above facts in the hope that they may prove of some interest in the question at issue, and to show that at least there are some exceptions to Mr. Wallace's statement that Alpine lakes only exist in glaciated regions.

I may add that Iake St. Clair has been accounted for by Gould, who explained it by supposing that a flow of basalt bad dammed up the lower end of tie valley in which the lake lies. I am, however, much inclined to doubt the existence of this basalt. Though we traversed the end of the lake where it is said to occur, we did not recognise any basalt.

It may also be remarked about the "button grass" flats or swamps, that they really occupy rock-basins, and may perhaps be regarded as the analogues of the peat-bogs of Scotland and Ireland. All those occurring in the same drainage area seem to be directly connected with each other, and I think there can be little doubt that many of them were formerly occupied by lakes. Melbourne University, May 7. Graham OfFickr.

THE Editor having given me the opportunity of reading $\mathrm{Mr}$. Graham Officer's interesting letter, I will make a few remarks upon it.

It seems to me that, without further information as to the nature of the search for drift, erratics, or ice-worn surfaces, and judging from the statement that the plateau studded with lakes and tarns was only looked down upon from an adjacent mountain summit, we can hardly give much weight to the positive statements, "I am confident that evidences of glaciation do not exist," and- "as I have shown, the glacier theory will not account for by far the greater number of the Alpine lakes on the great central green. stone plateau." Some light may perhaps be thrown on the matter by the consideration that the undoubted marks of glaciation in many parts of Australia are believed to have been caused by, comparatively, very ancient glaciers, since some of the glaciated surfaces are overlain by pliocene deposits, while others are believed to be of palæozoic age. If the Tasmanian glaciation was also of pliocene age, most of the superficial indications may have been destroyed by denudation, or, if preserved, may be hidden by vegetation or by alluvial deposits. We must therefore wait for a much more thorough examination of the district and of other parts of Alpine Tasmania before it can be positively stated that no evidences of glaciation exist. AlFRed R. Wallace.

\section{Vectors and Quaternions.}

I woulD like to ask Prof. Knott whether there would be any fatal objection to defining the scalar product of two vectors as equal to the product of their tensors into the cosine of the angle between them, so that, if the vectors are

and

$$
i x_{1}+j y_{1}+k z_{1}
$$

the scalar product would be

$$
i x_{2}+j y_{2}+k z_{2},
$$

and not

$$
x_{1} x_{2}+y_{1} y_{2}+z_{1} z_{2},
$$

$$
i x_{1} \cdot i x_{2}+j y_{1} \cdot j y_{2}^{\prime}+k z_{1} \cdot k z_{2} \text {. }
$$

If this is done, and, for the sake of associativeness of products, $i^{2}$ is made equal to - I, the distributive or quaternionic product of two (or more) vectors would be their vector product 